\title{
Material Aspects of Severan Legislation in the Light of Documentary Papyri
}

\section{Introduction}

The material form of a legal text-nowadays regulated in details and the conformity with established rules, which define: author, form and place of publication-is a condition of its legal validity. In analyzing Roman sources of law we often transpose this modern perspective, expecting that their validity also depends on a set of rules defining their linguistic form, issuing body and publication method.

According to a generally accepted view of romanistic doctrine which originates in the late 19th century, the period of great codifications of law, the Roman imperial constitutions are divided into four categories, which embrace: edicts (edicta), instructions for imperial administration (mandata), sentences issued in the extra ordinem process (decreta) and written opinions in respond to a legal question (rescripta). ${ }^{1}$ The latter were subsequently divided by Wilcken in letters (epistulae) and subscripts (subscriptiones). ${ }^{2}$ The modern authors define for each of the types its issuing office, language, literary style, publication method and the scope of normative application. ${ }^{3}$ This notion of Roman imperial law is rooted in the analysis of the constitutions collected in two large anthologies which came down to our times: the Codex Theodosianus and the Codex Justinianus. From this perspective, the imperial decisions known as $\dot{\alpha} \pi о к \rho i \mu \alpha \tau \alpha$, which are found in the papyri, are being identified with one of the known types of constitutions, most commonly with the subscripts. ${ }^{4}$

The aforementioned classification finds its confirmation in two fragments of ancient law handbooks called institutiones by two classical Jurists: Gaius ${ }^{5}$ and Ulpian ${ }^{6}$.

1 Kipp 1896, 66-77.

2 Wilcken 1920, 1-42.

3 Krüger 1912, 104-105; Schwind 1940, 128-184; Wenger 1953, 54-102; Coriat 1997.

4 Wilcken 1920, 21; Williams 1974, 88; D’Ors/Martin 1979, 120; Nörr 1981b, 23; Coriat 1997, 93; Haensch 2007, 214-216. 223-224; differently Turpin 1981, 145-160 identifies $\dot{\pi} о к р і н \alpha \tau \alpha$ as decreta, and Nörr 1983, 519-543 as interlocutiones de plano.

5 G.1.5: Constitutio principis est, quod imperator decreto uel edicto uel epistula constituit. Nec umquam dubitatum est, quin id legis uicem optineat, cum ipse imperator per legem imperium accipiat.

6 Ulp. 1 inst. D. 1.4.1: pr. Quod principi placuit, legis habet vigorem: utpote cum lege regia, quae de imperio eius lata est, populus ei et in eum omne suum imperium et potestatem conferat. 1. Quodcumque igitur imperator per epistulam et subscriptionem statuit vel cognoscens decrevit vel de plano interlocutus est vel edicto praecepit, legem esse constat. Haec sunt quas vulgo constitutiones appellamus. 2. Plane ex his

I would like to thank Thamar Xandry for her valuable comments on my paper.

๑ Open Access. () 2019 Anna Plisecka, publiziert von De Gruyter. (c) BY-NC-ND Dieses Werk ist lizenziert unter der Creative Commons Attribution-NonCommercial-NoDerivatives 4.0 Lizenz.

https://doi.org/10.1515/9783110641042-015 
Both texts deal with the definition of the term constitutio principis, but give a different delimitation of the expression: Gaius mentions only three subcategories: decreta, edicta and epistulae, while Ulpian adds two more: subscriptiones and interlocutiones de plano. None of the authors lists written instructions to the imperial magistrates (mandata), which are known as sources of law from other jurisprudential texts. ${ }^{7}$ Notwithstanding the fact that we could attempt to explain the differences between the aforementioned definitions claiming that the catalogue of imperial enactments changed between the 60's of the second century AD and the beginning of the third century AD, such explanation doesn't seem probable. It is implausible not only because of the short span of time between the two catalogues, but also because we do not have any information about a reform of the sources of law in that period. In addition it would not explain the lack of mandata in either of the definitions, particularly since we know that the mandata as sources of law were known to Ulpian. ${ }^{8}$ It seems that the most likely explanation is that there was no closed catalogue of imperial legislation and consequently the listed forms of constitutions are used merely as examples. ${ }^{9}$ The employed defining method by partition already points in this direction, for this type of definition doesn't have to be complete and consequently is suited to define res infinitae. ${ }^{10}$ It seems therefore presumable, that next to the abovementioned standard types of constitutions also other imperial pronouncements, that is to say also pronouncements not fulfilling any formal requirements, were considered legally binding. ${ }^{11}$ Consequently, it can be assumed that the normative impact of any imperial enactment employed in the legal practice is independent of the form and relies exclusively on the authority (auctoritas) of the lawgiver. ${ }^{12}$

A further argument for this hypothesis can be derived from the papyrological documents containing Severan $\alpha$ локрí $\mu \alpha \tau$. It has already been argued that the documentary evidence in many points completes the knowledge emerging from texts of strictly juristic character embraced in the Corpus Iuris Civilis. ${ }^{13}$ A closer look on the documentary evidence can affect in my opinion among other topics the abovemen-

quaedam sunt personales nec ad exemplum trahuntur: nam quae princeps alicui ob merita indulsit vel si quam poenam irrogavit vel si cui sine exemplo subvenit, personam non egreditur.

7 Ulp. 45 ad ed. D. 29.1.1 pr.; Ulp. 32 ad Sab. D. 24.1.3.1; Call. 5 de cogn. D. 48.19.27.1-2.

8 Ulp. 15 ad ed. D. 1.17.1: Praefectus Aegypti non prius deponit praefecturam et imperium, quod ad similitudinem proconsulis lege sub Augusto ei datum est, quam Alexandriam ingressus sit successor eius, licet in provinciam venerit: et ita mandatis eius continetur.

9 A new type of imperial enactment, interlocutio de plano, was identified by Nörr, who puts in question the known system of the constitutions with this hypothesis: Nörr 1983, 521-543.

10 Nörr 1981a, 590. On partitio and its use in the Writings of Gaius see Nörr 1972, 21, 46-53.

11 We find a confirmation of this view in the very same text of Ulpian 1 inst. D. 1.4.1 pr.: Quod principi placuit, legis habet vigorem.

12 Nörr 1972, 30.

13 Coriat 1997, 23-29. 
tioned typology of the imperial constitution based on their material form. In particular it allows questioning the dominant identification of $\alpha$ локрi $\mu \alpha \tau \alpha$ as subscripts.

The present paper is focused on a group of Severan constitutions, which consist in decisions issued in respect of private cases brought forward by petition of one of the parties. There are two groups of such constitutions: subscripts (subscriptiones) and

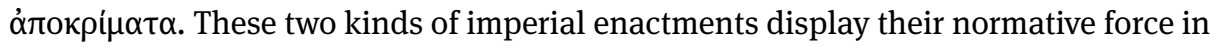
two different dimensions. In the first place they are binding for the particular case, for which they are issued; subsequently they can be employed as precedents in analogous cases. The binding force of the imperial decision in a particular case means that the magistrate judging the case is constrained to abide by the opinion of the emperor and, following the investigation of the circumstances described in the petition, he will have to confer or deny the right to the petitioner in conformity with that opinion. The impact of such decisions extends to subsequent similar cases in which they are used as a model (exemplum). In order to fulfil their second function the decisions were copied, sometimes even in thematic groups. ${ }^{14}$ In consequence the precedents obtain a general binding force through their repeated use in subsequent cases. This impact is demonstrated and described in literature both for subscripts and for $\alpha \dot{\pi} о к \rho i ́ \alpha \alpha \alpha{ }^{15}$ Because of their similar employment both $\alpha$ локрí $\mu \alpha \tau \alpha$ and subscripts are often identified with each other. ${ }^{16}$

Notwithstanding the fact that even the individual Latin constitutions cannot be every time framed into the above mentioned categories without difficulties, ${ }^{17}$ the romanistic doctrine still resources to them in explaining imperial sources of law. This statement is valid firstly for the imperial decisions named in the documents as

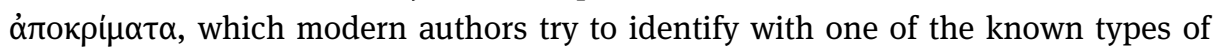
constitutions. ${ }^{18}$ Most commonly accepted is the hypothesis, which goes back to Wilcken, identifying them with a subcategory of rescripts, which are subscriptiones. ${ }^{19}$ Nevertheless already Wilcken remarked in a note on his groundbreaking paper that

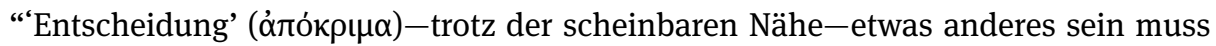
als 'Bescheid' (rescriptum)". ${ }^{20}$

The association of the $\dot{\alpha}$ токрí $\mu \alpha \tau$ with subscriptiones has its consequences for the interpretation of the former ones. In particular, since it has been convincingly

14 P. Stras. 22 (collection of various decisions on longi temporis praescriptio); P. Oxy. 1020 (collection of decisions on aetatis auxilium).

15 Katzoff 1972, 273-278.

16 Wilcken 1920, 21; Williams 1974, 88; D’Ors/Martin 1979, 120; Nörr 1981b, 23; Coriat 1997, 93; Haensch 2007, 214-216. 223-224.

17 Nörr 1981b, 6-11, 32; Peachin 2015, 211-222.

18 P. Col. 123; P. Amh. 63; P. Flor. 382; P. Oxy. 899; P. Oxy. 1020; P. Oxy. 1405 ll.1-13; BGU I 267; BGU II 473.

19 Wilcken 1920, 21; Casavola 1955, 92; Williams 1974, 88; D’Ors/Martin 1979, 120; Nörr, 1981b, 23; Coriat 1997, 93; Haensch 2007, 214-216, 223-224. Different opinion in: Lewis 1999, 97-98.

20 Wilcken 1920, 32, n.1. 
demonstrated that the subscripts were regularly formulated in Latin by the imperial office $a$ libellis, in the literature the opinion still prevails that all the $\alpha$ локрí $\mu \alpha \tau \alpha$ were not directly written in Greek, but translated from Latin. ${ }^{21}$

The aim of the present paper is to reflect on the material aspects of the Severan $\dot{\alpha} \pi о к \rho i \mu \alpha \tau \alpha$ in order to distil their peculiar features. The comparison between subscripts and $\alpha$ жокрі $\mu \alpha \tau \alpha$ demonstrates how important it is to consider divergent sources, papyri on the one hand and legal literature on the other hand, in order to understand the diversity of imperial lawmaking.

\section{The Severan ómoкрі́ $\mu \alpha \alpha$ in Comparison With subscriptiones}

\subsection{The Transmission}

The subscripts are mostly known via their versions collected in the codices of Theodosius and of Justinian. Those collections contain material selected for its legal relevance and composed for official purpose. Moreover, most changes introduced to the original text of the subscript were conscious decisions of the editors. ${ }^{22}$ In addition, there are two examples of subscripts from the time of Septimius Severus preserved in inscriptions. ${ }^{23}$

The $\alpha$ локрi $\mu \alpha \tau \alpha$, in contrast, are known from the papyri in which they are copied in most cases for private usage, as parts of documents to be presented in front of the magistrate. In some cases we have more than one copy of the same imperial decision. A brief look at these examples demonstrates that, even if they allow reconstructing the legal meaning of the issued decision faithfully, they differ in language and form. Therefore, only with great caution they can be taken as testimonies of the official chancellery style or serve for linguistic analysis.

The first example is the decision of Septimius Severus and Caracalla regarding acquisitive prescription, which is transmitted in two documents BGU I 267 from 199 AD and P. Stras. 22 composed after $217 \mathrm{AD} .^{24}$ The texts diverge not only in the formulation but also in their dating of the decision, according to the BGU I 267 the decision was issued on the 30 December 199, whereas according to P. Stras. 22 only on the 19 April $200 .{ }^{25}$

21 Coriat 1997, 588; Williams 1974, 102-103; Laffi 2013, 62 and n. 95.

22 Matthews 2000; Sirks 2007; Atzeri, 2008; Krüger 2010, 388-419.

23 CIL 6,3770 = 31330,5-7 (Severus paeanistis); CIL 3,14203,8 (31 May 204); see also Coriat 2014.

24 Amelotti 1958; Nörr 1969; Chevreau 2006, 108.

25 On the dating of the decision see Mitteis/Wilcken 1963, 286; FIRA I 438; Coriat 1997, 619. 
BGU I 267

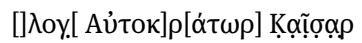

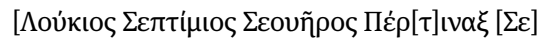

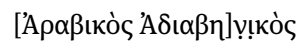

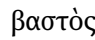

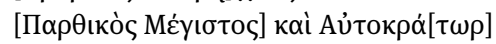

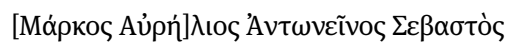

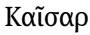

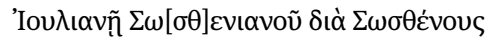

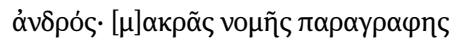

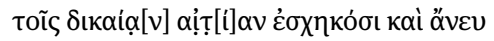

$\tau$

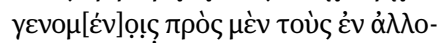

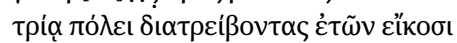

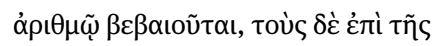

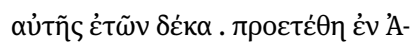

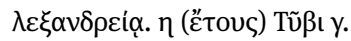

P. Stras. 22

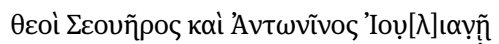

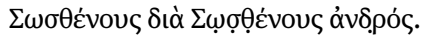

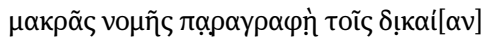

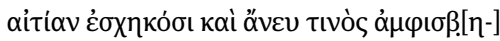

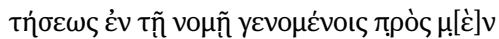

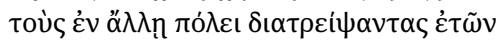

$$
\begin{aligned}
& \text { हौкобเ }
\end{aligned}
$$

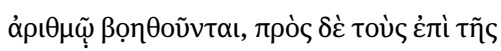

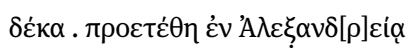

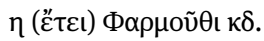

Imperator Caesar [L. Septimius Severus] Pertinax Augustus [Arabicus Adiabe]nicus [Parthicus Maximus] and Imperator Caesar [M. Aure]lius Antoninus Augustus to Juliana, the daughter of Sosthenianus, through her husband Sosthenes. The plea of long-lasting possession enters into force for those, who have a just cause and entered in possession without any controversy, against those namely who stay in a different city after twenty years, against those however who (stay) in the same city after ten years. Published in Alexandria in the eight year, Tubi $3 .^{26}$

The copy in the Strasbourg document is prepared less carefully than the one in $B G U$ I 267. ${ }^{27}$ The Berlin text opens with an extensive yet not complete titulature, which in

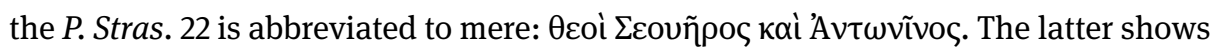
that the document was written not until after the death of Caracalla in 217 AD. This short formula is often employed in posthumous documents. ${ }^{28}$ The copy in P. Stras. has also other minor inaccuracies. Firstly it reports the patronym of the petitioner incorrectly as Sosthenes (P. Stras. 22 1. 2). Correct is instead the patronym Sosthenianus, which we read in BGU I 267 1.6. The mistake results probably from the circumstance that the name of the petitioner's husband, Sosthenes, is reported in the document right after the patronym. We cannot be sure about the difference between the formu-

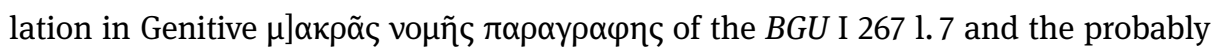

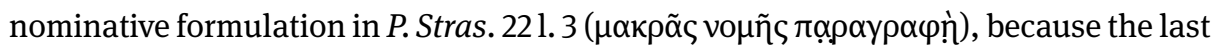
letter is reconstructed. We also find some expressions abbreviated in the Strasbourg

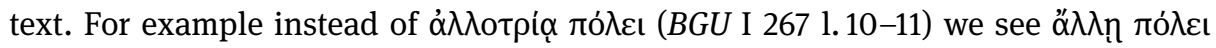

26 For the reasons stated below the text of the Papyrus BGU I 267 has been taken as the basis for the translation.

27 Eich 2009, 282-283.

28 Coriat 1997, 577-578; Eich 2009, 283 and 286 n. 78. 
(P. Stras. 221.6 ), or by defining the time limit for the prescription the word $\varepsilon \tau \tilde{\omega} \nu$ is omitted, which does not alter the meaning of the text. The place of residence of the petitioner is described in BGU I 2671.11 with the verb $\delta \iota \alpha \tau \rho \varepsilon i \beta \varepsilon ı v$ whereas in the document from Strasbourg we find a less suited future form $\delta \iota \alpha \tau i \dot{\psi} \psi \varepsilon \iota v$ (1. 6). Similarly

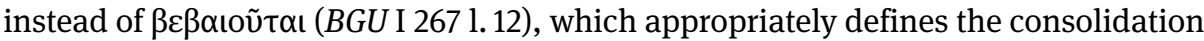
of the possessor's right after the elapse of time necessary for prescription, we find a

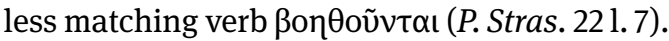

The few grammatical and terminological differences between the copies are irrelevant for the reconstruction of the legal meaning of the decision. The version reported in the $B G U$ I 267 should be considered closer to the original, whereas the divergences encountered in the P. Stras. 22 can all be identified as simplifications or copying mistakes, because the words which vary from the version in BGU I 267 both semantically and graphically are similar to the Berlin text.

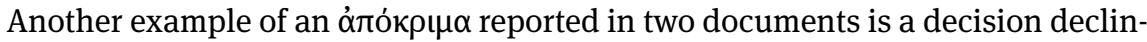
ing the right to appeal from a judgment which has already been accepted by the appellant, which we find both in P. Col.1231.8-10 and in P. Amh.631.1-6. The decision is dated in both documents on the 14 March 200.

P. Col. $1231.8-10$

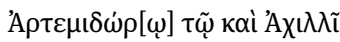

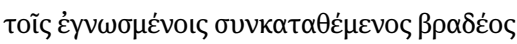

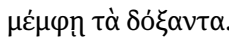

P. Amh. 63 1.1-6

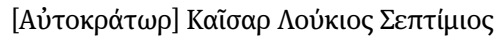

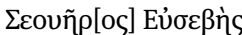

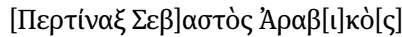

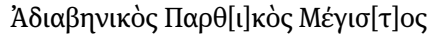

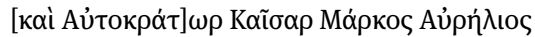

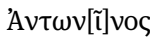

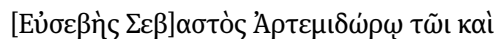

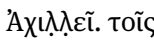

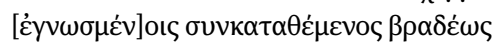
$\mu \varepsilon \dot{\varepsilon} \mu \eta\rceil \grave{\alpha}$

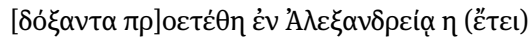
$\Phi \alpha \mu \varepsilon v \dot{\omega} \theta$ in.

[Imperator] Caesar L. Septimius Severus Pius [Pertinax] Augustus Arabicus Adiabenicus Parthicus Maximus [and Imperator] Caesar M. Aurelius Antoninus [Pius] Augustus to Artemidoros also called Achilles. Since you have declared to be in agreement with the decisions, it is too late to raise a claim against the judgements. Published in Alexandria in the eight year, Phamenoth 18.

Since the copy of the decision issued upon petition of Artemidoros also called Achilles contained in P. Amh. $631.1-6$ is reconstructed based on its version known from the Columbia papyrus, there are no differences between the two texts of the decision. We see however that the version from the Columbia papyrus is incorporated in a series of $\dot{\alpha} \pi о к \rho i \mu \alpha \tau \alpha$ and therefore is neither immediately preceded by the imperial titulature nor closed with the date.

The most interesting is the third example containing the decision on cessio bonorum, a procedure of ceding property by a person nominated to a liturgy, to which a 
candidate could resource in order to avoid exercising the office personally. This decision is transmitted in three different documents: P. Oxy. 14051.1-13, P. Oxy. 31051.1-10

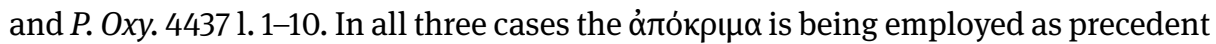
in a petition to the same strategos Aurelius Leonides.
P. Oxy. 3105 1-10
P. Oxy. 1405 1-13
P. Oxy. 4437 1-10

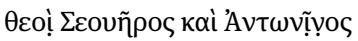

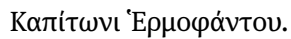

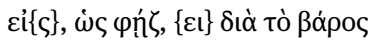

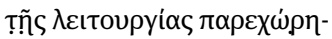

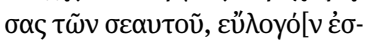
$\tau ı] \underline{\mu} \mu \grave{\eta} \tau \tilde{\omega} \tau \alpha \mu \varepsilon \dot{\omega} \omega \dot{\eta} \mu \tilde{\omega}(v)$

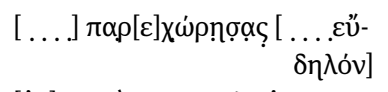

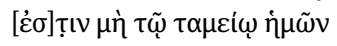

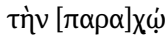

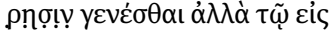

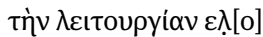

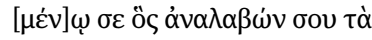

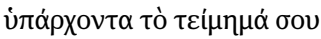

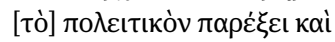

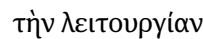

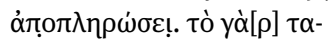 $\mu \varepsilon \tilde{0} 0 v \dot{\eta} \mu \tilde{\omega} \nu \tau \tilde{\omega} \nu$

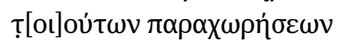

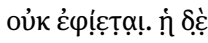

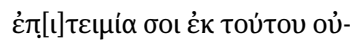

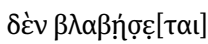

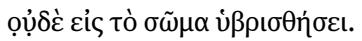

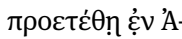

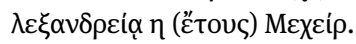
[-ca.11 - $] \rho[\ldots] \pi \alpha \rho \varepsilon \chi \omega \dot{\omega} \rho[\eta-]$

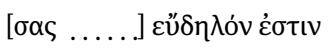
$\mu \eta ั \tau \tilde{\omega}$

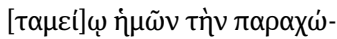

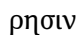

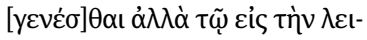 тoupyíav

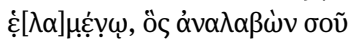 $\tau \grave{\alpha}$

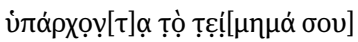 т̣̣ $[\pi \circ \lambda] !$

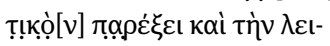

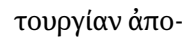

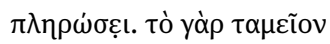 $\dot{\eta} \mu \tilde{\omega} v$

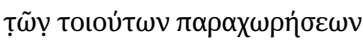

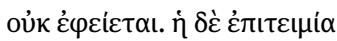 боv $\dot{\varepsilon}-$

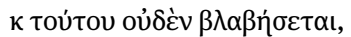

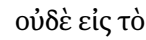

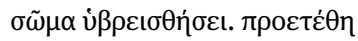 ¿́v $A \lambda \varepsilon \xi \alpha v-$

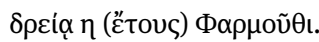

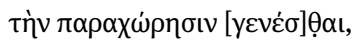

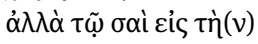 $\lambda ı \tau[o] v \rho y ı$ s

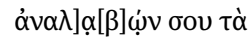

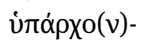

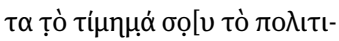

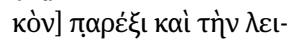

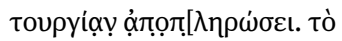

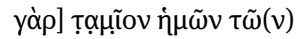

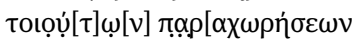

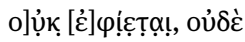

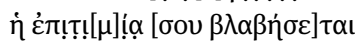

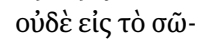 $\mu \alpha \llbracket \sigma o v \rrbracket \underline{u}[\beta] \rho ! \emptyset \sigma \eta \dot{\sigma c ̧ ̣ l . ~ \pi \rho o-~}$

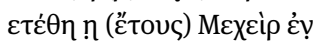

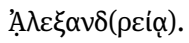

The deified Severus and Antoninus to Capito, the son of Hermophantus. If, as you claim, you ceded your property because of the burden of the liturgy, it is reasonable, that the cession is not made to our fiscus, but to the person who nominated you to the liturgy, who, after taking your property will give you an official estimation of your (property) and will fulfil the liturgy. For our fiscus does not desire such ceded properties and neither will your rights as citizen be limited nor will you be subject to corporal punishment. Published in the eight year, Mecheir, in Alexandria. ${ }^{29}$

29 The most complete text of the P. Oxy. 4437 1.1-10 was taken as the basis for the translation. 
The three copies of the órókрı $\mu \alpha$ diverge from each other merely in details. The document P. Oxy. 4437 reports the most complete version. It contains the abbreviated titulature, known already from $P$. Stras. 22, the address to Capito Hermophantus and the opening words of the decision. However the document seams less carefully prepared

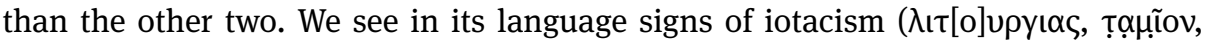
$\left.\pi \alpha \rho \varepsilon \xi_{l}\right)$, which are absent in the other two versions. Instead of the more suited word

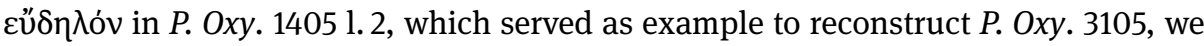

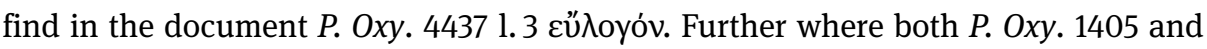

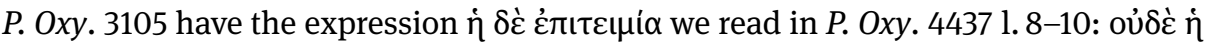

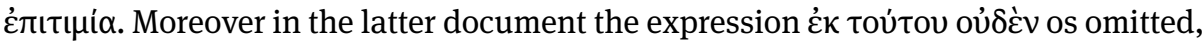
which we find in both P. Oxy. $14051.10-11$ and P. Oxy. 3105 1.9. Here again the small divergences between the documents do not obscure the legal meaning of the imperial decision. However all abovementioned examples illustrate that the copies were made privately and with certain degree of insouciance in respect to the form and wording of the decision. Therefore, they can only be taken with great caution as examples of imperial chancellery style. Even less can they serve to prove that the texts are translated from Latin.

\subsection{The Language of the $\alpha$ mокрí $\mu \alpha \tau \alpha$}

The first and most important difference between both kinds of enactments ( $\alpha$ локрі $\mu \alpha \tau \alpha$ and subscripts) is their language. With regard to the latter it is commonly agreed that they were always formulated in Latin. ${ }^{30}$ For this thesis speaks not only the fact that almost all the subscripts we know are written in this language, but also the fact that the imperial office $a$ libellis which was responsible for their issuing, in contrast with the department ab epistulis, which was dealing with the letters and edicts, was not divided in two branches according to the language. ${ }^{31}$ On the other hand, all the $\alpha$ локрi $\mu \alpha \tau \alpha$ are formulated in Greek. Since one of the criteria to include an imperial enactment in one of the defined categories is their language, it is often assumedas the consequence of the identification of the $\alpha$;локрi $\mu \alpha \tau \alpha$ with the subscripts-that the Greek of the $\alpha$ жокрi $\mu \alpha \tau \alpha$ is a mere translation from the Latin original. ${ }^{32}$

In both the Codex Theodosianus and Codex Justinianus only one Greek constitution is preserved. ${ }^{33}$ We know, however, on the basis of the documents preserved in the inscriptions and the papyri that imperial enactments formulated in this language

30 Casavola 1955, 93; D’Ors/Martin 1979, 13; Coriat 1997, 588-589.

31 Townend 1961a, 99-109; Townend 1961b, 375-381; Stanton 1975, 499.

32 Wilcken 1937, 235; Wilcken 1936, 111; Schiller/Westermann 1954, 47; Casavola 1955, 93; Pringsheim 1956, 239; Laffi 2013, 62.

33 Theodosius II and Valentinian (431 AD) CTh. 9.45.4; C.1.12.3, see Stolte, 2009, 147-159. 
were more frequent, especially in respect to letters and edicts. ${ }^{34}$ For the purpose of spreading the imperial law in the eastern provinces, the pronouncements of the emperor had to be rendered in Greek..$^{35}$ In the literature the view is popular, that the constitutions-as earlier the senatus consulta ${ }^{36}$-were always formulated in Latin and translated in Rome by imperial administration. ${ }^{37}$ They would be sent to the provinces already in Greek version, in order to avoid manipulations in the course of translation, or, as Wilcken has argued, simply to facilitate the understanding of the law by the local population..$^{38}$ This thesis is based on an observation that the Greek legal texts which are found in the eastern provinces of the empire generally follow a similar stylistic form and are all composed in koเvn. ${ }^{39}$

The idea that the statutes are to be published in Greek in the places where this language is dominant is also confirmed by Ulpian, who was himself running the imperial office a libellis under Septimius Severus, in a fragment of his commentary to the praetor's edict. ${ }^{40}$ In a text concerning a public notice, by which an entrepreneur could limit his added liability for a slave running his business (institor), ${ }^{41}$ the jurist states that it should be formulated in a language customary in the place of publication. In his description of requirements for such a notice to be legally binding Ulpian makes the analogy between the publication of the notice and the publication of the statutes, by adopting the expression unde de plano recte legi possit, which has a long tradition in the publication of official regulations. ${ }^{42}$ Greek language was thus for practical reasons widely employed in the publication of the imperial enactments. Such a situation

34 Oliver 1989, 1-24; Anastasiadis/Souris 2000, 1-21.

35 Eck 2004, 5-9.

36 Viereck 1888, xi; Sherk 1969, 13.

37 Coriat 1997, 587.

38 Wilcken 1936, 101-122.

39 Viereck 1888, xi; Sherk 1969, 13-19.

4028 ad ed. D. 14.3.11.3: Proscribere palam sic accipimus claris litteris, unde de plano recte legi possit, ante tabernam scilicet vel ante eum locum in quo negotiatio exercetur, non in loco remoto, sed in evidenti. Litteris utrum Graecis an Latinis? Puto secundum loci condicionem, ne quis causari possit ignorantiam litterarum. Certe si quis dicat ignorasse se litteras vel non observasse quod propositum erat, cum multi legerent cumque palam esset propositum, non audietur.

41 Fuhrmann/Liebs 1974, 34. 80-82; Fröschl 1987, 102-105; Wacke 1993, 33-37; Bürge 1999, 56-59; Miceli 2008, 69-70.

42 It has been used in 123/122 BC in the lex Acilia repetundarum 38: propositaque palam apud for [um, ubei de plano recte legi possitur (Crawford 1996, 65-112, nr. 1), later it can be found in the first century $\mathrm{AD}$ in the lex municipii Malacitani 51: pro/ponito ita $u(t)\{V\} d(e) p$ (lano) r(ecte) l(egi) $p$ (ossint) (CIL 2,1964) and frequently in the lex Irnitana 51.8; 63.11; 85.37; 86.23; 90.31; 95.10 (Wolf, 2011). Moreover it appears as an abbreviation V.D.P.R. L.P of a typical publication clause in the first century AD in de iuris notarum of the grammarian Marcus Valerius Probus (FIRA II S. 453-455; Girard/Senn 1967, 9-12). 
is both confirmed in the jurisprudential literature and documented in the papyri and inscriptions. ${ }^{43}$

In order to conciliate the theory of Latin as exclusive language of the imperial constitutions with the bright evidence of such legislation in Greek the romanistic doctrine resources to the hypothesis of translation as a common practice for the statutes intended for the eastern provinces. ${ }^{44}$ In consequence, it has to resource to the distinction between the language of formulation on the one hand, i. e. the language in which the text has originally been composed-which would always be Latin-and the language of publication on the other hand, which can be either the original Latin or a Greek translation. The Greek versions of the imperial enactments found in the documentary sources are therefore often classified as mere translations. ${ }^{45}$

This general assumption is based on a handful of documents in which the quoted imperial decision is described explicitly as translation from Latin. The oldest of such documents is the epistula of Hadrian to Rammius Martialis. ${ }^{46}$ The reconstruction:

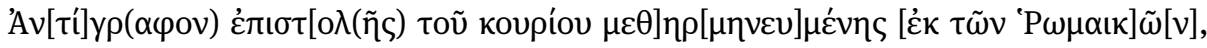
which suggests a translation from Latin, has been proposed by Stein, ${ }^{47}$ although already Meyer assumed that the letter was originally written in Latin. ${ }^{48}$ In fact, it would be difficult to imagine another language employed in the official letter intended for the Roman prefect Q. Rammius Martialis. The present copy however was made not from the original document, but from a Greek copy of it which was posted in Alexandria in the Quarters of the third Cyrenaic legion and of the twenty second Deioterian legion. ${ }^{49}$ We can assume that the letter, containing a grant of inheritance rights (bonorum possessio) to the children born to soldiers during their military service, was translated and posted for the information of the beneficiaries of this imperial grant. Therefore the reason is clear why the letter was formulated in Latin as well as the reason why it was translated into Greek. Nothing indicates that the Greek version has been received by the prefect together with the Latin original. To the contrary, the remark that the text was translated points in the direction that the document was translated locally. This document neither demonstrates that the imperial letters were officially translated by the office $a b$ epistulis, nor support the thesis that subscripts were regularly translated, because the latter ones were issued by a different imperial office, i. e. the office a libellis.

43 Fröschl 1987, 103, n. 81; Wacke 1993, 34 n. 83; Bürge 1999, 58.

44 Wilcken 1936, 111; Wilcken 1937, 235; Schiller/Westermann 1954, 47; Casavola 1955, 93; Pringsheim 1956, 239; Laffi 2013, 62.

45 Wilcken 1936, 111; Wilcken 1937, 235; Schiller/Westermann 1954, 47; Pringsheim 1956, 239; Laffi 2013, 62.

46 BGU I 140 = FIRA I 78 = Oliver 70, on this document Wilcken 1902, 84-94.

47 Stein 1950, 207, n. 212.

48 Meyer 1897, 46.

49 BGU I 140 = FIRA I 78 = Oliver 70 ll. 5-7. 
The second document demonstrating a translation of an imperial text from Latin into Greek is found in a copy of a subscript of Antoninus Pius to Usenophis ${ }^{50}$ from ca. $150 \mathrm{AD}$. In the document a subscript is cited in a translation from a Latin origi-

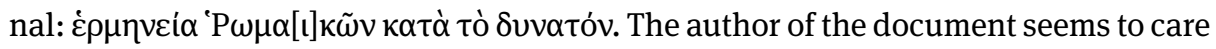
about notifying the reader, that the imperial decision is not reported in the original version. Furthermore he tries to justify possible deviations from the original by add-

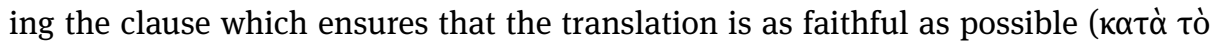

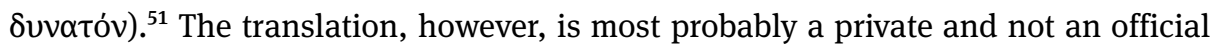

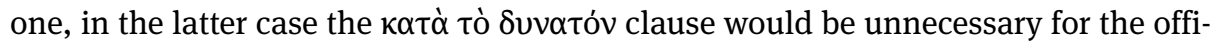
cial translation would have an equal legal value as the original. This document confirms Wilken's theory according to which the original language of the subscripts was Latin, ${ }^{52}$ but it speaks against the abovementioned hypothesis of centralized official translation. The single case of an imperial subscript translated from Latin into Greek can hardly demonstrate that the Greek texts of the $\alpha$ локрі $\mu \alpha \tau \alpha$ are also translations, for there are further differences between these both categories of texts.

The last example of translation into Greek is an edict of an unknown emperor from the second half of the third century, P. Harr. 202. The document contains two imperial enactments of which one can be a subscript, whereas the second one is an edict. In line 20 of the text we can read: $\alpha \tau \omega^{\text {'P }} \omega \mu \alpha \iota \kappa \alpha^{\prime} \cdot \mu \varepsilon[\tau$ '], which most probably indicates a translation from Latin. We know, that imperial edicts were published in the language used in the place where they were posted. ${ }^{53}$ Therefore in some cases it can be assumed that an edict intended exclusively for one of the eastern provinces was redacted directly in Greek. ${ }^{54}$ It seems consistent with the document P. Harr. 202 in which just before the information about translation from Latin another important note is added, which informs that the translated document was published in Rome. ${ }^{55}$ It is therefore a case of an edict written in Latin and published according to the general rule in that language in Rome. That edict was later translated into Greek, probably because of the personal interests of the author of the document.

Looking at the available evidence there are no convincing arguments for the assumption of a widespread practice of translating imperial constitutions written in Latin into Greek. In particular we don't see such practice for the imperial subscripts.

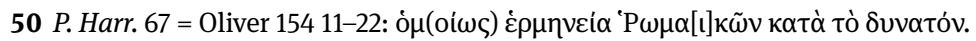

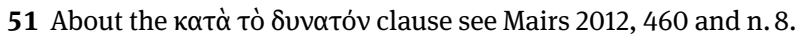

52 Wilcken 1920, 6-9; Wilcken 1937, 235.

53 The most known example is the edictum de pretiis issued by Diocletian, of which copies both in Greek and Latin were found in various provinces; c. fr. Blümner/Mommsen 1958; Lauffer 1971; Giacchero 1974; Crawford/Reynolds 1975, 160-163; Polichetti 2001.

54 Cfr. recently published Greek edict which seems to be formulated in this language, for it is free from latinisms: Hauken/Malay 2009, 333.

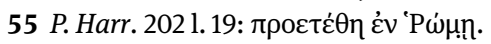




\subsection{Promulgation and Filing of the Imperial Constitutions}

The subscripts, which are the answers to private petitions, were according to Wilcken until the reign of Trajan sent directly to the petitioner, whereas only their copies were kept in the archives. The habit of posting them in public would have started later. ${ }^{56}$ In contrast, Williams argues that the habit of posting the imperial decisions in public started already with Augustus. ${ }^{57}$ In the romanistic literature the hypothesis is widespread that the subscripts were always published in the place where the emperor would sojourn. There are however documents proving differently. ${ }^{58}$

The office a libellis was writing the subscripts directly under the text of the private petition (libellus) on the same document, which was put forward by the suppliant. This circumstance is probably the reason why the texts of the subscripts are usually short and laconic. Notwithstanding the fact that numerous documents are available it is still difficult to define what exactly was happening with the documents after the emperor's signature. How were they posted, how were they archived and who was able to make copies of them?

The inscription from Scaptopara from the times of Gordian demonstrates that the subscribed libelli were attached together to form a liber libellorum rescriptorum et propositorum. ${ }^{59}$ From this phrase it can be assumed that the documents were firstly posted in public (praeposita) and subsequently put together to form one liber and as such archived. It has been proposed by Wilcken, and broadly accepted in the literature

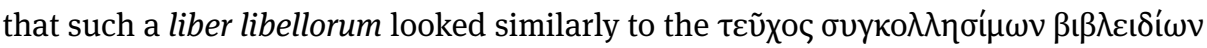
known from Egypt. ${ }^{60}$ The latter is a form of archiving which was implemented in Egypt under Roman influence and was mainly in use in the state archives for storing various kinds of documents. ${ }^{61}$ The same inscription informs us about the practice of authenticating copies obtained from the archived documents. ${ }^{62}$ The same authentication practice is known from other kinds of official and private documents written both in Latin and Greek, ${ }^{63}$ therefore such practice cannot be seen as characteristic for subscripts, but as a sign of a more general habit of authenticating documents. Authenticated copies of the subscripts could have been obtained as well during the period in which the document was posted, as later from the imperial archives. The entire petition together

56 Wilcken 1920, 90; D’Ors/Martin 1979, 117.

57 Williams 1974, 98.

58 Nörr 1981b, 34-35.

59 The inscript of Scaptopara (CIL 3,12336 = IGBulg 4,2236 = AE 1994 1552); see the commentary by Hauken 1998, 98-105.

60 Wilcken 1920, 36-37; Wilcken 1930, 19-20 followed by Williams 1976, 237; Williams 1980, 293-294; Sperandio 2005, 75-84.

61 Clarysse 2003, 344-359.

62 CIL 3,12336 = IGBulg 4,2236 = AE 19941552 1. 2: descriptum et recognitum factum. About the formula see Williams 1975, 63.

63 For the list of the documents see: Hauken 1998, 99-104. 
with the subscript was the basis both for the praepositio and for the archive. Notwithstanding the fact that we don't see the petition in the subscripts reported in Justinian's codex, there are examples of such composed documents in the inscriptions. ${ }^{64}$

We dispose of little information about publication and archiving of the $\alpha$ локрí $\mu \alpha \tau \alpha$. It is known that they were collected in groups and posted in public for three to six days. In this time both the petitioner and other interested persons could have procured copies of the documents. ${ }^{65}$ A papyrus from Yale confirms that the petitioners in the cases of petitions to the prefect of the province could copy the exposed documents themselves and later could obtain an official confirmation stating that their copies are conform with the original. ${ }^{66}$ It could have been possible also for the $\alpha$ локрí $\mu \tau \alpha$, but there is so far no direct evidence for such practice.

Since the $\alpha$ токрі $\mu \alpha \tau \alpha$ were posted publically, they were intended not only for the supplicant himself, but also to other interested persons as information about the effective law. According to Coriat local jurists were producing copies of the $\dot{\alpha} \pi$ окрí $\mu \alpha \tau \alpha$, because imperial decisions represented an important instrument for the local legal practice. ${ }^{67}$ This view is confirmed by numerous copies of the $\alpha \dot{\pi}$ окрі $\mu \alpha \tau \alpha$, some of which we see reported in two or even three different documents. ${ }^{68}$

Both subscripts and $\alpha$ кокрi $\mu \alpha \tau \alpha$ were in the Severan times publically posted. We know that the subscribed libelli were subsequently archived. ${ }^{69}$ We assume however from the existing material, that the subscripts were posted together with the petition, which can be deduced from the expression liber libellorum rescriptorum et propositorum. On the contrary, $\dot{\alpha} \pi о к \rho i \mu \alpha \tau \alpha$ are never copied together with the petition. Even when more consecutive decisions are copied in the same document, as is the case in P. Col. 123, there are never traces of the petitions between the $\alpha$ rокрi $\mu \alpha \tau \alpha$, despite the fact that some decisions are incomprehensible without the petition. We can see here a parallel with the decisions issued by the provincial governor, which also do not

64 The most interesting example is the inscription from Scaptopara (CIL 3,12336 = IGBulg 4,2236 $=A E 1994$ 1552) which reports a complet text of a Greek petition together with the Latin subscript of the emperor Gordian cfr. Hauken 1998, 74-139.

65 Williams argues that the tabula Banasitana was an exception, Williams 1974, 95. In the text of the document we read in 1.21: descriptum et recognitum ex commentario ciuitate Romana. The document copied is however an imperial letter, not a subscript (1. 14: Exemplum epistulae Imperatorum Antonini et Commodi Augg(ustorum)).

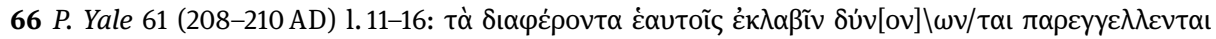

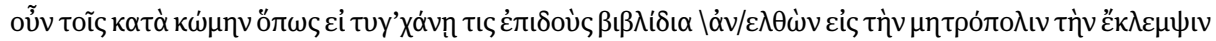

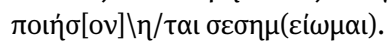

67 Coriat 1997, 624-627.

68 A decision declining the right to appeal from a judgement which has been accepted: P. Col. 123 11. 8-10 und P. Amh. 63 1l. 4-7; a decision about cessio bonorum is reported in three different petitions: P. Oxy. 1405 11. 1-13, P. Oxy. 3105 1l. 1-10 and P. Oxy. 4437 1l.1-10; another decision regarding longi temporis praescriptio is copied in two documents: BGU I 267 und P. Stras. 22.

69 Hauken 1998, 98. 
contain the original petition, but only the address to the petitioner.$^{70}$ Moreover, some documents report decisions which can be interpreted as replies to more than one petition. ${ }^{71}$ It seems therefore, in the light of available evidence, that the $\alpha \pi$ лорі $\mu \alpha \tau \alpha$ were published without the petition. In consequence of such publication some decisions, deprived of their original context, are difficult or impossible to understand. For this reason their value as precedents is limited. The lack of petition in all the known documents can mean that $\alpha$ токрi $\mu \alpha \tau \alpha$ were not only posted but also archived separately of the petitions, if we assume that they were archived. The latter hypothesis is plausible because we find copies of $\alpha$ локрí $\mu \alpha \tau \alpha$ in documents issued as late as 20 years after they have been posted. ${ }^{72}$ Even a more radical hypothesis has been considered: the

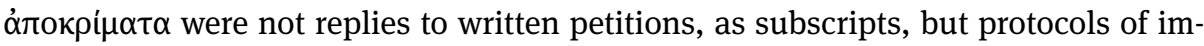
perial decisions taken orally. ${ }^{73}$ This hypothesis would explain the lack of petition, but raise the question why only the decision was recorded in writing, nor would it explain the decisions that seem to apply to a group of similar cases.

\subsection{The Characteristics of the ómокрí $\mu \tau \alpha$ in Comparison With the Subscripts}

The aforementioned remarks allow me to put a question mark over the dominant identification of the $\alpha$ жокрi $\mu \alpha \tau \alpha$ with the subscripts. Therefore, in following the particular characteristics of the $\dot{\alpha} \pi$ окрí $\mu \alpha \tau \alpha$ will be addressed in detail in order to formulate a hypothesis to their identity.

The most particular characteristic for the $\alpha$ локрí $\mu \alpha \tau \alpha$ are place and circumstances of their publication. All but two of the imperial decisions defined in papyri as $\dot{\alpha} \pi о к \rho i ́ \alpha \tau \alpha$ were published in a relatively short span of time between December 199 and April 200 AD, during the visit of Septimius Severus and Caracalla to Egypt. ${ }^{74}$ There are only two papyri in which an imperial decision described in the document as

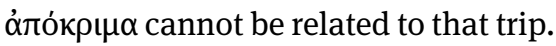

The first case is the P. Mich. 529 from 232-236 AD, in which an earlier decision of Septimius Severus and Caracalla is quoted. A second copy of the same decision, which was taken in an oral procedure, ${ }^{75}$ can be found in a Berlin Papyrus $7216 .{ }^{76}$ In

70 Nörr 1981b, 5.

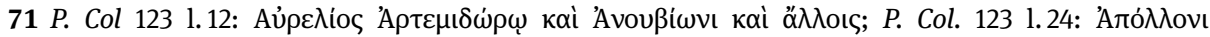

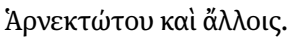

72 P. Oxy. 1405; P. Oxy. 3105 and P. Oxy. 4437.

73 Turpin 1981, 145-160.

74 P. Amh. 63; P. Col. 123 (= SB 6,9526); P. Flor. 382 1-4 and 24-26; BGU I 267 and II 473 1-12; P. Oxy. 899

1l. 18-21; P. Oxy. 1020; P. Oxy. 1405 1-13; P. Oxy. 3018; P. Oxy. 3105, 1-10; P. Oxy. 4437; P. Oxy. 4068; P. Stras.

22; $S B$ 4,7350 and 10,10537.

75 Lewis 1976, 324.

76 Edited by Świderek 1975, 293-298. 
both documents the decision is reported as precedent in a process. There are however divergences between the papyri which are relevant for qualifying the decision

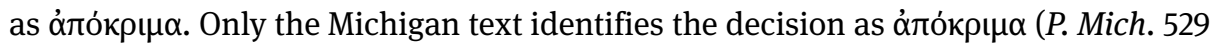
1. 25) ${ }^{77}$ and, at the same time, it identifies both Septimius Severus and Caracalla as its

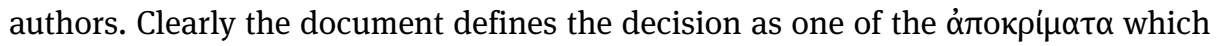
were issued during the stay of both emperors in Egypt at the turn of 199 and 200 AD. In contrast, the document from Berlin presents the decision as issued by Caracalla alone during his stay in Egypt in the year 215. Furthermore, the latter document doesn't use

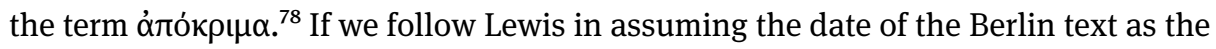
correct one for the decision and dating it 15 years later, then the P. Mich. 529 would

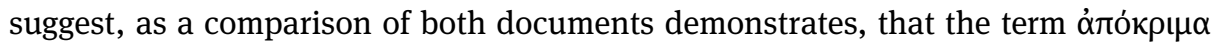
was used to describe the decisions taken by Septimius Severus and Caracalla during their stay in Egypt at the turn of the 199 and 200 AD. Such conclusion can be drawn from the fact that only the P. Mich. 529, which mistakenly attributes the decision to both Septimius Severus and Caracalla, defines it as $\alpha$ ло́крц $\mu$. It is striking that 30 years after the sojourn of Septimius Severus and Caracalla in Egypt, the $\alpha$ локрi $\mu \alpha \tau \alpha$ issued by them were still very popular, ${ }^{79}$ however the exact memory which decisions exactly were issued by the occasion has already perished. In consequence sometimes other decisions were attributed to both emperors and described as $\alpha$ локрi $\mu \alpha \tau \alpha$. In the case of the P. Mich. 529, even if the decision reported was indeed issued 15 years later, by Caracalla alone, the term $\alpha$ róкрц $\mu \alpha$ is clearly employed in connection with the decisions of 199 and 200 AD.

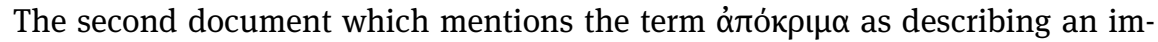
perial decision taken before the trip of Septimius Severus and Caracalla to Egypt is P. Tebt. II 286 (= M. Chr. 83 = FIRA III 100). The document, which employs the term to describe a decision taken by Hadrian on unjust possession, ${ }^{80}$ was composed after the emperor's death. The decision is quoted as a precedent in a process in front of the

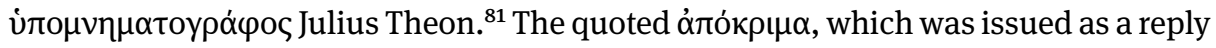
to a petition of a plaintiff in conflict with a women named Philothera, was itself based

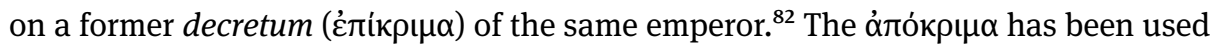
as precedent for the first time in the year $121 \mathrm{AD}$ and later has been followed in further

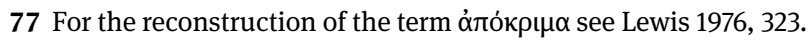

78 About the date of the document see Lewis 1976, 320-330.

79 See the decision on the cessio bonorum used as precedent in three different petitions from the years 229-236 AD: P. Oxy. 1405 1.1-13, P. Oxy. 3105 1. 1-10 and P. Oxy 4437 1. 1-10.

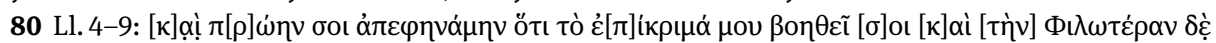

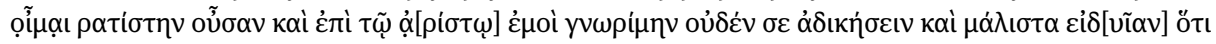

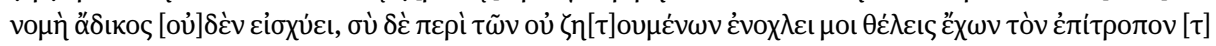

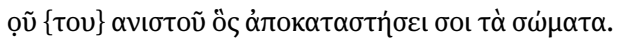

81 Oliver 1989, 173-174.

82 Katzoff 1972, 274. 
processes. ${ }^{83}$ Since the mentioned Philothera has a Greek name, it is possible that the case took place in one of the eastern provinces. The decision itself, however, since it was taken still before the first trip of Hadrian, was issued most probably in Rome. In

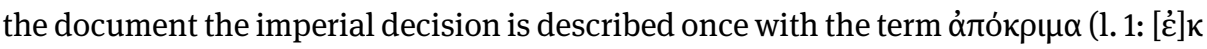

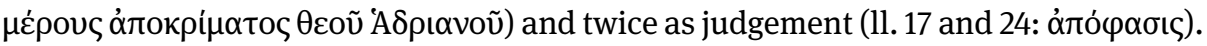
The latter term should be understood here in its general meaning, and should not be interpreted as corresponding to the Latin term decretum, because the latter is correctly

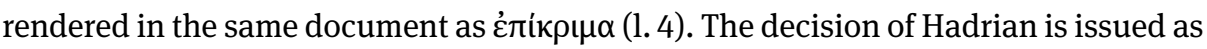
a judgement in an ongoing process. When we consider that in order to describe that decision the author of the document uses not only the term áróкрı $\mu \alpha$, but also a more

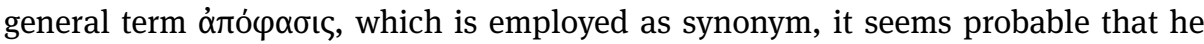
doesn't aim at giving a strict technical meaning to the term. On the contrary, it seems that the word $\alpha$ локкц $\mu \alpha$ is employed in the present document without any technical meaning. Probably the word did not have a defined technical meaning in the times of Hadrian. The Tebtunis papyrus is the first occurrence of the word $\alpha$ ók $\rho \mu \alpha$ and it is circa 60 years earlier as all the other known examples. It is striking, that all other texts in which the term is used refer to the decisions which have been taken in a relatively short span of time during the sojourn of Septimius Severus and Caracalla in Egypt and were later employed as precedents in the local courts. The hypothesis can therefore be formulated, that the word $\alpha$ กо́крц $\alpha$ which was in use already in the times of Hadrian didn't yet have particular technical meaning, and only in the time of the stay of Septimius Severus and Caracalla in Egypt or shortly after came to identify specifically a group of imperial decisions which were taken and published at this occasion. The term $\alpha$ л́к $\rho \iota \mu \alpha$ from the beginning of the third century AD onwards would be used in Egypt consistently to refer to a specific group of imperial decisions which were also used as precedents in the legal practice. The $\alpha$ токрi $\mu \alpha \tau \alpha$ would represent therefore a different imperial act than subscripts. This hypothesis can be supported also by further arguments deriving from a closer look at the imperial subscripts issued exactly in the time of the sojourn of Septimius Severus and Caracalla in Egypt.

\subsection{Severan subscriptiones From the Period of the Sojourn of the Emperors Septimius Severus and Caracalla in Egypt}

We find in the code of Justinian three subscripts from the period of the stay of Septimius Severus and Caracalla in Egypt. The first was issued upon petition of Munatius on the 24 February $200 \mathrm{AD}\left(\right.$ C.8.44.1) ${ }^{84}$ Another one is an answer to a petition in form

83 In the year $121 \mathrm{AD}$ in the process of Apollonides vs. Claudius Antoninus in front of the iudex Flavius Juncinus, later in the process of Ptolema in front of the iudex Julius Theon, it will still probably serve as precedent to the owner of the document reported in P. Tebt. 286; see Katzoff 1972, 273-275.

84 Imperatores Severus, Antoninus. Emptor hereditatis rem a possessoribus sumptu ac periculo suo 
of a letter of Secundus given on the 15 April 200 AD (C.8.37.1) ${ }^{85}$ The third subscript was issued for Theogenes on the 21 April $200 \mathrm{AD}$ (C.6.2.1). ${ }^{86}$ All three documents are written in Latin. We have no information about the place of their publication, only in the last case the name of the petitioner indicates that the plea came possibly from a Greek person.

These texts demonstrate that during the period in which the $\alpha$ локрi $\mu \alpha \tau \alpha$ were issued the office a libellis continued its regular work issuing subscripts. When we take a closer look on the dating of the Latin documents we see that they are dated with consular dates following the Roman calendar. It can indicate that they were issued and posted in Rome. The $\alpha$ локрі $\mu \alpha \tau \alpha$ in contrast are dated according to the Egyptian calendar and they regularly mention Alexandria as publication place.

\section{Conclusion}

The abovementioned considerations demonstrate that $\alpha$ локрi $\mu \alpha \tau \alpha$ have their particular characteristics in respect to their language, as well as to the circumstances and place of their publication. These characteristics distinguish them from other known forms of imperial constitutions and indicate that they represent an imperial enactment sui generis. The decisions known as $\alpha$ токрi $\mu \alpha \tau \alpha$ were issued in Alexandria in local language and tackle important aspects of provincial life such as liturgies ${ }^{87}$, inheritance ${ }^{88}$ and property ${ }^{89}$, therefore they had primary relevance for the local legal practice. These circumstances are responsible for the success of the $\alpha$ локрi $\mu \alpha \tau \alpha$ in Egypt and the fact that they were often copied so that we find some in multiple copies. Additionally, we can assume that the decisions were not numerous and remained in

\footnotetext{
persequi debet. Evictio quoque non praestatur in singulis, cum hereditatem iure venisse constet, nisi aliud nominatim inter contrahentes convenit (Sev. et Ant. AA. Munatio. A 200 pp. VI K. Mart. Severo II et Victorino conss.).

85 Imperatores Severus, Antoninus. Licet epistulae, quam libello inseruisti, additum non sit stipulatum esse eum cui cavebatur, tamen si res inter praesentes gesta est, credendum est praecedente stipulatione vocem spondentis secutam (Sev. et Ant. AA. Secundo. A 200 accepta XVII K. Mai. Severo II et Victorino conss.).

86 Imperatores Severus, Antoninus. Si pecunia tua mandantibus servis quidam praedia comparaverunt, eligere debes, utrum furti actionem et condictionem an mandati potius inferre debeas. Neque enim aequitas patitur, ut et criminis causam persequaris et bonae fidei contractum impleri postules (SEV. ET ANT. AA. Theogeni. A 200 D. XI K. MAI. Severo II et Victorino conss.).

87 P. Col. 123 1l. 36-40 (15 Marz 200 AD); P. Flor. 382 1l. 1-4 (22 February 200 AD); P. Oxy. 3018 1l.1-5 (13 April 200 AD); P. Oxy. 1405 (236/7 AD); P. Oxy. 3105 (229-235 AD); P. Oxy. 4437 (229-237 AD); BGU II 473 1l. 1-12 (= M. Chr. 375).

88 P. Col. 123 1l. 28-34 (15 March 200 AD); P. Col. 123 11. $25-27$ (15 March 200 AD); P. Col. 123 1l. 52-56 (16 March 200 AD).

89 BGU I 267; P. Stras. 22.
} 
use for a relatively long time. Since we know only a limited number of the decisions issued in a short period of time, we can assume that they were not issued repeatedly. In the latter case, we would expect newer decisions to substitute the older ones, but we find the $\dot{\alpha} \pi о к \rho i \mu \alpha \tau \alpha$ quoted even after the decease of Caracalla.

An occasion for this group of imperial decisions to be issued was the sojourn of Septimius Severus and Caracalla in Alexandria. Probably this singular situation impacted also the development of the word $\alpha$ лóкрц $\mu$, which initially had not yet a definite technical meaning, which is demonstrated by its employment in the P. Tebt. 286. Only after the stay of Septimius Severus and Caracalla in Egypt the term came to indicate the imperial decisions issued in that period. The $\alpha$ токрi $\mu \alpha \tau \alpha$ are therefore answers of the emperors to pleas from private persons which were formulated in Greek and posted in public in Alexandria. Their interpretation is hindered by the fact that we know only the laconic answers, but not the petitions which triggered them. From the examples we possess today we can assume, that the emperors were often pleaded to reconsider an earlier decision, probably taken by a local official. In those cases Septimius Severus and Caracalla would frequently maintain the previous decision. ${ }^{90}$ Sometimes the emperor disposes that the case should be reexamined by the prefect. ${ }^{91}$ In most cases the emperor states the existing law to be applied in a particular case..$^{92}$ In none of the cases is the question definitely resolved for the petitioner. It seems that the emperor did not examine the cases in detail, i. e. examining the validity of the alleged proves, documents or witnesses.

The employment of the $\alpha$ токрí $\mu \alpha \tau \alpha$, which do not correspond to any of the known types of imperial constitutions, in the legal practice as precedents demonstrates that next to the typical imperial constitutions like edicta, decreta, mandata, epistulae and subscriptiones also other pronouncements of the emperors could have obtained normative force.

The $\alpha$ жокрí $\mu \alpha \alpha$ demonstrate the importance of documentary evidence for the study of Roman imperial constitutions. Moreover, they prove on the one hand that the imperial enactments could have been issued directly in Greek and on the other that there were no formal requirements for their legal validity. In consequence, $\dot{\alpha} \pi о к \rho i \mu \alpha \tau \alpha$ furnish yet another argument for the thesis, that there was no closed catalogue of imperial constitutions and any imperial pronouncement independently on

90 P. Col. 123 1l. 8-10 (14 March 200 AD); P. Amh. 63 1l.4-7 (14 March 200 AD); P. Col. 123 ll. 11-12 (14 March 200).

91 P. Col. 123 1l. 45-51 (16 March 200 AD); P. Col. 123 Z.13-17 (14 March 200 AD).

92 BGU I 267 (30 December 199 AD) = P. Stras. 22 1l. 1-9 (19 April 200); P. Col. 123 1l. $35-39$ (15 March 200); P. Oxy. 3018 ll. 1-5 (13 April 200 AD); P. Flor. 382 1l. 1-4 (22 February 200 AD); P. Oxy. 3018 ll. 1-5 (13 April 200); P. Oxy. 1405 (236/7 AD); P. Oxy. 3105 (229-235 AD); P. Oxy. 4437 (229-237 AD); BGU II 473 ll. 1-12 = M. Chr. 375 (March/April 200 AD); P. Amh. 63 ll. 1-6 (14 March 200 AD) = P. Col. 123 ll. 5-7 (14 March 200 AD); P. Col. 123 ll.22-24 (15 March 200 AD); P. Col. 123 ll. $41-44$ (16 March 200 AD); P. Col. 123 11. 18-20 (14 March 200 AD). 
the language and form could have obtained the force of law. Since there were no formal requirements which the emperor would be obliged to follow in order to emanate a legally binding opinion, the sole basis for their validity was his auctoritas.

\section{Bibliography}

Amelotti, Mario (1958), La prescrizione delle azioni in diritto romano (Fondazione Guglielmo Castelli 24), Milan.

Anastasiadis, Vasilis I./Souris, George A. (2000), An Index to Roman Imperial Constitutions from Greek Inscriptions and Papyri, Berlin/New York.

Atzeri, Lorena (2008), Gesta senatus romani de theodosiano publicando: Il codice Teodosiano e la sua diffusione ufficiale in occidente (Freiburger rechtsgeschichtliche Abhandlungen. N. F. 58), Berlin.

Blümner, Hugo/Mommsen, Theodor (1958²), Der Maximaltarif des Diokletian, Berlin.

Bürge, Alfons (1999), "Sprachenvielfalt und Sprachgruppen im Rechtsleben der Stadt Rom - Gedanken zu D. 14.3.11.3 und zum Umgang mit Fremdsprachen im heutigen bürgerlichen Recht", in: Jean-François Gerkens (ed.), Mélanges Fritz Sturm: offerts par ses collègues et ses amis à l'occasion de son soixante-dixième anniversaire, vol.1, Liège, 53-63.

Casavola, Francesco Paolo (1955), “Diritto dialogato in P. Col. 123”, in: Labeo 1, 90-97.

Chevreau, Emmanuelle (2006), Le temps et le droit: La réponse de Rome. L'approche du droit privé, Paris.

Clarysse, Willy (2003), “Tomoi Synkollesimoi”, in: Maria Brosius (ed.), Ancient Archives and Archival Traditions: Concepts of Record-keeping in the Ancient World, Oxford, 344-359.

Coriat, Jean-Pierre (1997), Le prince législateur. La technique législative des Sévères et les méthodes de création du droit impérial à la fin du principat (Bibliothèque des Ecoles Françaises d’Athènes et de Rome 294), Rome.

Coriat, Jean-Pierre (2014), Les Constitutions des Sévères. Règne de Septime Sévère, hg. von J.-P. C., vol.1, Rome.

Crawford, Michael H./Reynolds, Joyce (1975), "The publication of the prices edict: a new inscription from Aezani”, in: The Journal of Roman Studies 65, 160-163.

Crawford, Michael H. et al. (1996), Roman Statutes, vol.1, London.

D’Ors, Alvaro/Martin, Fernando (1979), “Propositio libellorum”, in: American Journal of Philology 100, 111-124.

Eck, Werner (2004), “Lateinisch, Griechisch, Germanisch ...? Wie sprach Rom mit seinen Untertanen", in: Luuk de Ligt, Emily Hemelrijk, Henk W. Singor (eds.), Roman Rule and Civic Life: Local and Regional Perspectives. Proceedings of the fourth Workshop of the International Network Impact of Empire (Roman Empire, c. 200 B.C. - A.D. 476) Leiden, June 25-28, 2003, Amsterdam, 3-19.

Eich, Armin (2009), “Diplomatische Genauigkeit oder inhaltliche Richtigkeit? Das Verhältnis von Original und Abschrift", in: Rudolf Haensch (ed.), Selbstdarstellung und Kommunikation. Die Veröffentlichung staatlicher Urkunden auf Stein und Bronze in der Römischen Welt (Internationales Kolloquium an der Kommission für Alte Geschichte und Epigraphik in München, 1. bis 3. Juli 2006) (Vestigia 61), Munich, 267-299.

Fröschl, Johanna Maria (1987), “Imperitia litterarum. Zur Frage der Beachtlichkeit des Analphabetismus im Römischen Recht”, in: Zeitschrift der Savigny Stiftung für Rechtsgeschichte. Romanistische Abteilung 104, 85-155. 
Fuhrmann, Manfred/Liebs, Detlef (1974), Fälle aus dem römischen Recht (Ratio 5), Bamberg.

Giacchero, Marta (1974), Edictum Diocletiani et Collegarum de pretiis rerum venalium (Pubblicazioni dell'Istituto di storia antica e scienze ausiliarie dell'Università di Genova 8), Genova.

Girard, Paul Frédéric/Senn, Felix (1967), Textes de Droit Romain, vol. I (Pubblicazioni della Facoltà di Giurisprudenza della Università di Camerino 12), Dalloz.

Haensch, Rudolf (2007), “Apokrimata und Authentica. Dokumente römischer Herrschaft in der Sicht der Untertanen”, in: Rudolf Haensch (ed.), Herrschen und Verwalten. Der Alltag der römischen Administration in der hohen Kaiserzeit (Kölner historische Abhandlungen 46), Cologne/Weimar/Vienna, 213-234.

Hauken, Tor/Malay, Hasan (2009), "A New Edict of Hadrian from the Province of Asia”, in: Rudolf Haensch (ed.), Selbstdarstellung und Kommunikation. Die Veröffentlichung staatlicher Urkunden auf Stein und Bronze in der Römischen Welt (Internationales Kolloquium an der Kommission für Alte Geschichte und Epigraphik in München, 1. bis 3. Juli 2006) (Vestigia 61), Munich, 327-348.

Hauken, Tor (1998), Petition and Response. An Epigraphic Study of the Petitions to Roman Emperors 189-249 (Monographs from the Norwegian Institute at Athens 2), Bergen.

Katzoff, Ranon (1972), “Precedents in the Courts of Roman Egypt”, in: Zeitschrift der Savigny Stiftung für Rechtsgeschichte. Romanistische Abteilung 89, 256-292.

Kipp, Theodor (1896), Die Geschichte der Quellen des römischen Rechts, Leipzig.

Krüger, Paul (1912²), Geschichte der Quellen und Literatur des römischen Rechts (Systematisches Handbuch der Deutschen Rechtswissenschaft: Abt. 1, Theil 2), Munich/Leipzig [1888].

Krüger, Paul (2010), “Die Praefatio zum Codex Justinianus (übersetzt von Gisela Hillner)”, in: Zeitschrift der Savigny Stiftung für Rechtsgeschichte. Romanistische Abteilung 127, 364-428.

Laffi, Umberto (2013), In greco per $i$ Greci. Ricerche sul lessico greco del processo civile e criminale romano nelle attestazioni di fonti documentarie romane (Pubblicazioni del CEDANT 12), Pavia.

Lauffer, Siegfried (1971), Diokletians Preisedikt (Texte und Kommentare 5), Berlin.

Lewis, Naphtali (1976), “The Michigan - Berlin Apokrimata”, in: Chronique d'Egypte 51, 320-330.

Lewis, Naphtali (1999), “Apokrima. Où en est-on aujourd'hui?”, in: Revue historique de droit français et étranger 77, 97-98.

Mairs, Rachel (2012), “Interpreters and translators in Hellenistic and Roman Egypt”, in: Actes du $26 e$ Congrès international de papyrology (Genève, 16-21 août 2010) (Recherches et rencontres 30), Genève, 457-462.

Matthews, John (2000), Lying Down the Law. A Study of the Theodosian Code, New Haven.

Meyer, Paul (1897), “Die ägyptischen Urkunden und das Eherecht der römischen Soldaten”, in: Zeitschrift der Savigny Stiftung für Rechtsgeschichte. Romanistische Abteilung 18, 44-74.

Miceli, Maria (2008), Studi sulla "rappresentanza" nel diritto romano, vol. 1 (Università di Palermo, Facoltà di Giurisprudenza 17), Milan.

Mitteis, Ludwig/Wilcken, Ulrich (1963), Grundzüge und Chrestomathie der Papyruskunde, vol. 2.1, Hildesheim [reprint 1912].

Nörr, Dieter (1969), Die Entstehung der longi temporis praescriptio (Arbeitsgemeinschaft für Forschung des Landes Nordrhein-Westfalen. Geisteswissenschaften 156), Cologne/Opladen.

Nörr, Dieter (1972), Divisio und partitio. Bemerkungen zur römischen Rechtsquellenlehre und zur antiken Wissenschaftstheorie (Abhandlungen zur rechtswissenschaftlichen Grundlagenforschung 4), Berlin.

Nörr, Dieter (1981a), “Aporemata Apokrimaton (P. Columbia 123)”, in: Proceedings of the XVI International Congress of Papyrology, Chico (CA), 575-604.

Nörr, Dieter (1981b), “Zur Reskriptenpraxis in der hohen Prinzipatszeit”, in: Zeitschrift der Savigny Stiftung für Rechtsgeschichte. Romanistische Abteilung 98, 1-46. 
Nörr, Dieter (1983), “Zu einem fast vergessenen Konstitutionstypus: Interloqui de plano”, in: Christoforo Cosentini (ed.), Studi in onore di Cesare Sanfilippo, vol. 3 (Pubblicazioni della Facoltà di Giurisprudenza 96), Milan, 519-543.

Oliver, James Henry (1989), Greek Constitutions of Early Roman Emperors from Inscriptions and Papyri (Memoirs of the American Philosophical Society 178), Philadelphia.

Peachin, Michael (2015), “Weitere Gedanken zum Prozess des Verfassens kaiserlicher Reskripte”, in: Ulrike Babusiaux/Anne Kolb (eds.), Das Recht der "Soldatenkaiser". Rechtliche Stabilität in Zeiten politischen Umbruchs?, Berlin/Munich/Boston, 211-224.

Polichett, Antonio (2001), Figure sociali merci e scambi nell' 'edictum Diocletiani et collegarum de pretiis rerum venalium' (Università degli studi del Molise, Dipartimento di scienze giuridicosociali e dell'amministrazione 7), Naples.

Pringsheim, Fritz (1956), “Some Suggestions on P. Col. 123 (Apokrimata)", in: Eos 48 (1) (= Symbolae Raphaeli Taubenschlag dedicatae, vol.1), Bratislava/Warsow, 237-249.

Schiller, Abraham Arthur/Westermann, William Linn (1954), Apokrimata. Decisions of Septimius Severus on Legal Matters. Text Translation and Historical Analysis, New York.

Schwind, Fritz von (1940), Zur Frage der Publikation im römischen Recht mit Ausblicken in das altgriechische und ptolemäische Rechtsgebiet (Münchener Beiträge zur Papyrusforschung und antiken Rechtsgeschichte 31), Munich.

Sherk, Robert Kenneth (1969), Roman Documents from the Greek East. Senatus consulta and epistulae to the Age of Augustus, Baltimore.

Sirks, Adriaan J. Boudewijn (2007), The Theodosian Code. A Study (Studia Amstelodamensia 39), Friedrichsdorf.

Sperandio, Marco Urbano (2005), Codex Gregorianus. Origini e vicende (Pubblicazioni dell'Istituto di diritto romano e dei diritti dell'Oriente mediterraneo 80), Naples.

Stanton, Greg R. (1975), “Marcus Aurelius, Lucius Verus and Commodus: 1962-1972”, in: Aufstieg und Niedergang der römischen Welt, vol. 2.2, Berlin/New York, 478-549.

Stein, Arthur (1950), Die Präfekten von Ägypten in der römischen Kaiserzeit, Bern.

Stolte, Bernard H. (2009), "The Use of Greek in the Theodosian Code”, in: Subcesiva Groningana 8, 147-159.

Świderek, Anna (1975), “Une nouvelle copie de P. Mich. IX 529.25-38”, in: Proceedings of the XIVth International Congress of Papyrologists (Oxford, 24-31 July 1974), Oxford, 293-298.

Townend, Gavin B. (1961a), “The Hippo Inscription and the Career of Suetonius”, in: Historia 10, 99-109.

Townend, Gavin B. (1961b), "The Post ab epistulis in the Second Century”, in: Historia 10, 375-381.

Turpin, William (1981), "Apokrimata, decreta, and the Roman Legal Procedure”, in: The Bulletin of the American Society of Papyrologists 18, 145-160

Viereck, Paul (1888), Sermo graecus quo senatus populusque romanus magistratusque populi romani usque ad Tiberii caesaris aetatem in scriptis publicis usi sunt examinatur, Göttingen.

Wenger, Leopold (1953), Die Quellen des römischen Rechts (Denkschriften der Gesamtakademie / Österreichische Akademie der Wissenschaften 2), Vienna.

Wilcken, Ulrich (1902), "Ein neuer Brief Hadrians", in: Hermes 37, 84-94.

Wilcken, Ulrich (1920), “Zu den Kaiserreskripten”, in: Hermes 55, 1-42.

Wilcken, Ulrich (1930), “Zur propositio libellorum”, in: Archiv für Papyrusforschung und verwandte Gebiete 9, 15-23.

Wilcken, Ulrich (1936), “Ueber den Nutzen der lateinischen Papyri”, in: Atti del IV Congresso internazionale di Papirologia (Firenze, 28 aprile - 2 maggio 1935) (Pubblicazioni di Aegyptus. Serie scientifica 5), Milan, 101-122.

Wilcken, Ulrich (1937), “Urkunden Referat”, in: Archiv für Papyrusforschung und verwandte Gebiete 12, 218-247. 
Williams, Wynne (1974), “The Libellus Procedure and the Severan Papyri”, in: The Journal of Roman Studies 64, 86-103.

Williams, Wynne (1975), “Formal and Historical Aspects of Two New Documents of Marcus Aurelius", in: Zeitschrift für Papyrologie und Epigraphik 17, 37-78.

Williams, Wynne (1976), "Two Imperial Pronouncements Reclassified”, in: Zeitschrift für Papyrologie und Epigraphik 22, 235-245.

Williams, Wynne (1980), “The Publication of Imperial Subscript”, in: Zeitschrift für Papyrologie und Epigraphik 40, 283-294.

Wolf, Joseph Georg (2011), Die Lex Irnitana: ein römisches Stadtrecht aus Spanien: lateinisch und deutsch (Texte zur Forschung 101), Darmstadt. 